\title{
SECURITIES TRANSACTION TAXES FOR U.S. FINANCIAL MARKETS
}

\author{
Robert Pollin \\ University of Massachusetts-Amherst \\ Dean Baker \\ Center for Economic and Policy Research (CEPR) \\ Marc Schaberg \\ Independent Economic Consultant
}

\section{INTRODUCTION}

What are the most effective means of regulating volatile financial markets? Such a question may have appeared quaintly old-fashioned after the repeal of the GlassSteagall regulatory system in the United States in 1999 and the corresponding dismantling of financial market regulations throughout the world. But, like a hardy perennial, the question has quickly returned as one consequence of the collapse of the U.S. stock market and ensuing recession. Similar questions were also posed in the aftermath of the 1998 Asian financial crisis, which prompted widespread discussions on the need for a "new financial architecture." Many proposals were made after the Asian crisis. But they varied widely as to what form this new structure should take. Meanwhile, as this debate proceeded, the process of deregulation continued to advance.

This paper attempts to examine with some specificity the viability of security transaction excise taxes (STETs) as one significant component of a new financial architecture, while also making clear that, by itself, a STET can have only limited effectiveness as a means of achieving increased financial stability. The focus of the paper is on designing a STET as it would apply to the contemporary U.S. financial markets. But we also examine principles for designing a STET that will have general applications beyond any specific country setting.

STETs have been utilized extensively throughout the world both as a means of discouraging short-term speculative trading on financial markets and as a significant source of government revenue. Such a tax was proposed for the United States by then House of Representatives speaker Jim Wright after the 1987 stock market crash, and variations on this idea have been introduced fairly regularly in Congress in subsequent years, without ever having been passed into law.

The basic idea of a STET is simple. Imposing a small tax on a security transaction-for example a 0.5 percent tax on equity trades—would create a negligible bur-

Robert Pollin: Department of Economics and Political Economy Research Institute (PERI), University of Massachusetts, Amherst, MA 01003-7510. E-mail: pollin@econs.umass.edu. 
den on asset owners who intend to hold their asset for the long term. However, if asset owners purchase equity with the intention of selling it at a profit in the shortterm, the 0.5 percent tax would be imposed on each trade, and would thus constitute a significant burden. As James Tobin has put it, a STET "would automatically penalize short-horizon round trips, while negligibly affecting the incentives for ... longerterm capital investments, " [1996, xi].

The so-called Tobin Tax-a STET that applies to foreign currency markets onlyhas received increasing attention in recent years [ul Haq, Kaul, and Grunberg, 1996], as the details on the design of that idea have developed beyond Tobin's initial fundamental contribution [1978]. Beyond these discussions, however, little mention was made of STETs generally in the wake of the multiple crises of 1998, perhaps in part because over the previous decade most governments that had such taxes in place have either repealed them or sharply limited their scope. As of April 1999, for example, Japan had completely abolished its STETs. As recently as 1989, the STET generated more than four percent of the country's total government revenue [Japanese Securities Research 1992, 244], but the government had been reducing the tax in stages through the 1990s amid the country's long-term financial crisis.

The case against STETs has been made not just in the political arena. Multiple arguments within academic research have been raised against STETs over the past decade: they are difficult to design in ways that avoid severe distortions; they damage the competitive position of domestic financial markets in countries that have STETs relative to countries that do not; they raise the cost of capital and thereby discourage investment; and, finally, they are unlikely to either significantly dampen market volatility or raise significant tax revenue.

General arguments in support of STETs have been made before, initially by Keynes in the General Theory [1936], and recently by, among others, Summers and Summers [1989] and Stiglitz [1989]. The aim of this paper is not primarily to restate or amplify these general positions, but rather to explicitly address the critiques of STETs that have emerged in recent years. In particular, for the U.S. financial market, we show how to design a STET in ways that avoid the distortions noted by critics with respect to various STETs around the world. Once design problems are solved, we are then able to show that, for the U.S. case, the revenue potential of a STET is formidable-on the order of 70-100 billion dollars a year, or about five percent of total federal government outlays, even if one allows for declines in trading volume up to an implausible fifty percent of existing levels. Of course, assuming the STET is designed well, such substantial increases in government revenue will be accompanied by a decline in short-term speculative trading, and thus an increase in the government's ability to handle macroeconomic problems resulting from unstable financial markets.

The paper is organized as follows. We present some basic arguments why financial markets will operate with greater stability when STETs are one feature of a new financial architecture aimed at contributing to financial stabilization. In reaching this conclusion, we consider the various factors affecting market volatility and recognize the possibility that a STET could create ambiguous effects under some situations. We also point out that even if a STET fails to reduce financial market instabil- 
ity it will nevertheless generate a large amount of tax revenue through taxing unproductive activity.

We continue by looking at the general level of STETs as they have been applied throughout the world. We also present evidence on the extent to which STETs are being reduced or repealed in most places in the world. We also report on the small STET that does now operate in the United States for the purposes of financing the Security and Exchange Commission.

We then consider the major arguments against the STET that we raised above: that STETs are ineffective at reducing volatility; that they will raise the cost of capital and thereby discourage private fixed investment; and that they will create serious distortions between taxed and untaxed market segments.

Recognizing these potential problems, we continue by showing how the STET can be designed to minimize market distortions. Three main principles are elucidated: that coverage of the tax be as broad as possible, spanning all domestic market segments and foreign as well as domestic traders; that the tax rate be equivalent, based on the market value of assets being traded; and that the tax should also reflect existing differences in transaction costs in various markets.

From here, we move to estimating orders of magnitude for revenue estimates. As we will see, the revenue figures are quite large, on the order of $\$ 100$ billion, even after allowing for implausibly large declines in both trading values and volumes. We conclude with brief comments.

\section{WHY A STET?}

Investors in capitalist economies are faced with the unavoidable problem of uncertainty: forecasts and projections aside, "we simply do not know," as Keynes put it, how profitable a prospective investment project will be. The problem is compounded by the fact that current investment decisions will themselves influence future outcomes because they will affect the level of aggregate activity. A primary purpose of financial markets is to ameliorate problems due to uncertainty through increasing the liquidity of investments for asset owners. When financial instruments are freely traded in relatively thick markets, individual asset owners can transform their illiquid investments in plant and equipment into claims that are convertible into cash or other liquid assets as quickly as the institutional and technological structures permit. Of course, as Keynes emphasized, the stock of physical assets does not disappear from the economy as a whole just because ownership claims on them may readily move from one trader's portfolio to another's. Moreover, the fact that the physical assets themselves do not disappear-regardless of who claims ownership on themhas important economic consequences in its own right. This is because the growth of new investment in plant and equipment is sensitive to the rate at which firms utilize their existing productive capacity.

Nevertheless, thick financial markets do clearly provide a benefit to wealth holders by enabling them to purchase claims on long-lived physical assets without having to make long-term commitments to holding these assets. But proponents of the so-called "efficient market" theory of financial markets contend that the benefits of 
thick financial markets extend well beyond this basic contribution. According to the efficient market approach, thick financial markets correctly evaluate firms according to their "fundamentals" (that is, their potential profitability). Thus, a thick financial market is engaged in crucial information processing and price discovery activities. As a result, the profit potential of firms becomes widely disseminated. Moreover, the fact that information on fundamentals is widely disseminated forces firms to operate more efficiently. It becomes more difficult for firms to hide their deficiencies, and these deficiencies are widely recognized and punished by market participants. Correspondingly, financial market traders are rewarded for trading firms at prices that reflect fundamentals, and are punished for trading at prices that misread fundamentals. Over time, in other words, good traders drive out bad traders. It follows from this perspective that any significant interference with the market, such as a STET, will be harmful. ${ }^{1}$

As a first principle, then, the case for a STET must flow out of a critique of the efficient markets perspective. Critics, of course, still recognize the social benefits of being able to easily trade in markets for existing assets. At the same time, enhancing the liquidity of assets also creates problems for the functioning of the economy. Fundamentally, these problems flow from the fact that highly liquid financial markets promote speculative trading practices that distort pricing, resource allocation, and investment, creating imbalances between financial and real activity, and thereby contributing to macroeconomic instability. As such, excessive speculative financial trading is a form of unproductive activity in precisely the sense of Bhagwati's [1982] notion of "directly unproductive profit seeking," by which he means activities that may be privately profitable but do not directly increase the flow of goods and services.

Efficient market proponents have offered evidence showing that increasing stock market liquidity enhances long-run economic growth. Perhaps the most influential recent work on this issue is the econometric model by Levine and Zervos which draws on data from 47 countries from 1976 to 1993. They found that stock market liquidity, measured in various ways, is "a robust predictor of real per capita gross domestic product growth, physical capital growth and productivity growth" [1998, 538], after controlling for a range of other potential sources of growth. But Zhu, Ash, and Pollin [2004] have demonstrated that the Levine/Zervos findings are not robust. Indeed, once one utilizes various appropriate measures to control for outliers, no statistical evidence exists at all to support the claim that countries will enjoy faster economic growth through more liquid stock markets. This refutation of the Levine/ Zervos results is consistent with a broader set of empirical studies showing no relationship between stock market liquidity and growth [Arestis, Demetriades and Luintel 2001]..$^{2}$

But how do speculative financial markets distort pricing, resource allocation, and investment? Keynes presented the most influential critique of speculative financial market practices in Chapter 12 of the General Theory. Moreover, Keynes briefly proposes in this same discussion a securities transaction tax for the U.S. economy "with a view to mitigating the predominance of speculation over enterprise," [1936, 160]. But the critical literature has developed widely since Keynes. One important 
strand of work has been that of Shiller [1989; 2000], who emphasizes the role of investor psychology, independent of individual firm fundamentals, as a major determinant of stock market prices. As Shiller writes, stock prices "change in substantial measure because the investing public en masse capriciously changes its mind, [1989, 1]." Shiller's most recent book, Irrational Exuberance [2000] examines in detail the social and psychological "anchors" that determine stock market prices beyond what might be explained by fundamentals. Moreover, because these anchors are by their nature fragile, they are subject to unexpected and sometimes rapid reversals. In Shiller's view, this explains the fact that the stock market fluctuates well beyond what can be explained by fundamentals.

Related to Shiller's critique are arguments about the centrality of asymmetric information in financial markets, and specifically the influence exerted by ill-informed "noise traders." For example, in Shleifer's [2000] presentation of the "behavioral finance" perspective, he models financial markets as containing two kinds of traders, fundamental traders and noise traders. But noise traders are not competed out of the market by the fundamental traders in this perspective. This is because arbitrage is risky, costly, and therefore limited. For example, when stock prices are inflated relative to fundamentals, arbitreurs who choose to sell short face potential losses from prices moving still higher under the influence of noise traders; that is, their short-selling will not necessarily drive prices down to fundamentals. Thus, the actions of noise traders are not merely ephemeral to market activity, but rather exert a sustained influence on price formation.

This perspective is developed further, and specifically in considering the case for a STET, in Subrahamanyam's recent modeling exercise in which he argues,

Excessive rent seeking occurs in financial markets. That is, agents spend too many resources trying to acquire information just hours or days before other agents: this expenditure is a deadweight loss to society since it is unlikely that managers can benefit from information being incorporated into prices earlier by a matter of hours or a few days. A reasonable policy goal can thus be to reduce the efforts invested by agents in acquiring information just hours or days before others. [1998, 83]

But a deeper point about Keynesian uncertainty also emerges from this perspective. If markets are persistently and unpredictably moved away from fundamentals by noise traders, it no longer becomes logical for even well-informed traders and professionals to try to trade on the basis of fundamental information. It rather follows that professional traders should proceed as Keynes argued, to trade by trying to outguess market sentiment, moving ahead of the herd by "anticipating what average opinion thinks average opinion to be," [1936, 156]. As one important measure of this, Evans [2003] shows that the 1990s U.S. stock market bubble was significantly influenced by the large growth in mutual fund trading activity. Evans' econometric findings show that the impact of these professional traders influenced equity prices to a statistically significant extent, independently of the behavior of firms' revenue 
and profitability. As such, one might even argue that while "fundamentals" such as revenue, sales, and profitability certainly exist as valid performance standards for firms, they do not exist as the "fundamental" bases on which firms are valued-or even could be valued-in markets driven by what average opinion thinks average opinion will be. ${ }^{3}$

Overall then, according to these critical perspectives, thick but unregulated financial markets operate inefficiently and irrationally. But this, in itself, doesn't mean such activities necessarily inflict serious damage on broader economic performance. Are there broader harmful effects?

One broader effect of excessively speculative financial markets is that they tend to encourage short-term thinking among both investors and managers. The highly liquid financial markets enable investors to sell assets at low transaction costs whenever they are dissatisfied with a firm's performance, for example, in response to a firm's unsatisfactory quarterly return. This creates persistent pressure for shortterm success, to which managers in turn respond by gearing their investment projects and ongoing operations toward satisfying the short-term horizons of financial market investors. As a result, highly speculative financial markets tend to discount projects that require long-term nurturing before generating profitable returns. In surveying U.S. corporate managers in the early 1990s, Poterba and Summers [1995] found that U.S. managers believe that U.S. equity markets undervalue long-term investments and that they therefore are forced to operate with shorter time horizons than they deemed appropriate. Were the firms valued more in accordance with the perceptions of managers, managers believe that their long-term investments would increase, on average, by perhaps as much as 20 percent.

The more dramatic negative effect of speculative financial markets results, of course, when herd-like activities lead to market sell-offs, which in turn engender interactive asset deflations and financial crises. The destructive effects of financial crises are not hard to find. Writing in 2002, the most obvious example is the collapse of the U.S. stock market bubble, which then also exposed the excessive amounts of productive capacity and debt that corporations had accumulated while the bubble was in its expansion phase. The excessive supply of productive capacity and debt, in combination with the collapsed stock market, in turn produced the 2001 recession and stalled recovery of 2002 . But this is only the most recent dramatic example in what has become an ongoing series of recent financial crises, including the 1997-98 Asian crisis, the 1995 Mexican crisis, and the U.S. Savings and Loan crisis of the early 1990s. ${ }^{4}$ Note here that markets for fixed-income securities are just as susceptible as equity markets to the allure of the herd and that the social costs of speculative finance are equivalent regardless of whether they originate in stock, bond or derivative markets.

Finally, excessively liquid financial markets weaken the standard tools of macroeconomic stabilization and expansion, and a STET can therefore strengthen these same tools. As Minsky [1986] argued, standard fiscal and monetary policy tools cannot bring the economy to a full employment equilibrium when financial markets are highly speculative. Depending on the specific circumstances, including those in the nonfinancial economy, full employment will instead promote either euphoric expec- 
tations among those investors who would benefit from a boom or unfavorable expectations among investors whose fixed-income securities would lose value in an inflationary environment. As a result, policymakers must respond to the expectations of these investors rather than the underlying conditions of the nonfinancial economy.

How effective would a STET be in discouraging these types of harmful effects of volatile financial markets? We consider the question in some detail below when we survey the critics' arguments against STETs. Even before addressing the critics, however, it is crucial to recognize that the STET can have only a limited impact in controlling financial volatility. This is because, over the course of a business cycle, volatility is affected by three partially independent influences: the underlying behavior of the nonfinancial economy; the herd behavior of financial market participants; and the attempt by participants to dig out of financial crises once they have already occurred. ${ }^{5}$ The first two sources of volatility should be moderated through a decline in the liquidity of financial markets, and thus by a STET. However, the third source of volatility would be exacerbated by a decline in market liquidity. This is because more liquidity in the short term is precisely what financial market participants need to prevent an interactive debt deflation. In the midst of a crisis situation, therefore, the policy intervention needed is lender-of-last-resort intervention, not a STET. It is therefore not surprising, as we will see, that the critical empirical literature on STETs finds that the impact of higher transaction costs on volatility is ambiguous.

At the same time, the ability of lender-of-last-resort interventions to neutralize speculative financial herds is greater when the size of the herd is smaller. This is most evident in the case of currency markets. As of 1979, daily trading on world currency markets was 6.8 percent of central banks' foreign currency reserves. By 2000, daily currency market trading had exceeded central banks reserve holdings. Central banks now have far less capacity to serve as a market-maker to counteract speculative stampedes. Therefore, when a currency market crisis breaks out, the fact that a STET has reduced the market's liquidity may not directly reduce volatility. But it will have contributed toward stabilizing the market if, over a longer timeframework, it has reduced the size of the market and therefore enabled the marketmaker to exert greater influence during a crisis.

The effectiveness of the STET needs to be evaluated within a still broader perspective. We have been considering the STET within the framework introduced by Keynes, as an instrument for mitigating "the predominance of speculation over enterprise." However, to the extent that the STET fails to reduce speculative trading, it will, nonetheless, generate government revenues-and do so through taxing activities that are unproductive in the sense of not enhancing economic growth even if they are privately profitable. Below, we show that this revenue source is potentially quite large (on the order of $\$ 70-100$ billion per year). Further, because financial market trading is heavily dominated by the relatively wealthy, the tax incidence will be highly progressive. In short, assuming the tax can be well-designed to minimize distortions, the STET offers a classic "win-win" opportunity: it will either succeed by reducing excessive financial speculation; or it will fail to reduce such activity, but consequently still be successful by generating a large amount of government rev- 
enue that can be applied to productive public purposes. A well-designed STET, moreover, also offers a middle ground between these alternatives: the tax rate could be adjusted up or down according to whether the primary concern of policy was to reduce excessive financial speculation or to increase government revenue. More generally, the STET would provide government policymakers with an important additional policy instrument, both for reducing financial market instability and to raise revenues in a progressive way.

\section{PATTERNS OF STETS THROUGHOUT THE WORLD}

Security transaction taxes have been a common policy tool throughout the world. Table 1 shows the range of taxes of roughly the magnitude we are proposing that have operated in 38 countries in the recent past. As the table shows, most of the major financial markets in the world, including Japan, the U.K., Germany, Italy and France, have operated with some version of a STET. The table also shows that smaller OECD economies such as Australia, Austria, Belgium, Denmark, Greece and Ireland, and many emerging economies, such as Chile, China, India and Malayasia, have also operated with STETS. STETS have thus been used as a policy tool in a wide range of countries. But in recent years, the STETs have been reduced or eliminated in most of the countries listed. We have tried to provide a summary picture of the current status of this trend in Table 1 . Though we have not fully surveyed the debates in each country around the issue, we feel safe in saying that a primary motivation for reducing or eliminating the tax has been the perception that the taxes are distortionary, and that, in particular, removing the tax will make the domestic financial market more competitive in attracting foreign financial flows.

The United States stands out among the advanced OECD economies for never having instituted a significant STET. Nevertheless, there have been smaller STETs in the United States at various times. A federal stock transfer tax was in place from 1914 to 1966 . From 1960 to 1966 , stocks were taxed at the rate of 0.1 percent at issuance and 0.04 percent on transfer. Bonds were taxed at the rate of 0.11 percent at issuance and 0.05 percent at transfer. New York State also imposed a stock transfer tax. The tax rate varied depending on the value of the shares being traded; the average rate in 1968 was approximately 0.19 percent [Epps, 1976, 177].

While these taxes have been eliminated, the federal government still imposes a small tax on both the registration of new equity issues and their transfer, the proceeds of which primarily finance the operations of the Securities and Exchange Commission. In 2000 , the taxes were $1 / 36^{\text {th }}$ of one percent $(0.028$ percent $)$ of the value of a share registered and the transfer fee was $1 / 300^{\text {th }}$ of one percent $(0.0033$ percent $)$ of the value of a transferred share. Together, these taxes generated $\$ 2.2$ billion in revenue, nearly six times more than 2000 federal budget allocation of $\$ 370$ million for the SEC. Thus at present, most of the funds generated by the SEC registration and transfer taxes are already being allocated to the general Treasury fund. ${ }^{6}$

Of course, these tax rates are much smaller and more narrowly targeted than the STET we propose. Moreover, the rates on both taxes are scheduled to fall in 2007 - the registration tax to $1 / 150^{\text {th }}$ of one percent, and the transfer tax to $1 / 800^{\text {th }}$ of 
TABLE 1

Security Transaction Taxes around the World

\begin{tabular}{|c|c|c|c|c|c|}
\hline Country & Stocks & $\begin{array}{c}\text { Corporate } \\
\text { Bonds }\end{array}$ & $\begin{array}{c}\text { Government } \\
\text { Bonds }\end{array}$ & Futures & Detail \\
\hline Argentina & $0.60 \%$ & $0.60 \%$ & $0.60 \%$ & $0.60 \%$ & $\begin{array}{l}\text { Tax of } 0.6 \% \text { on all financial trans- } \\
\text { actions approved by legislature } \\
\text { March } 2000\end{array}$ \\
\hline Australia & $0.30 \%$ & $0.15 \%$ & - & - & $\begin{array}{l}\text { Reduced twice in } 1990 \mathrm{~s} \text {; cur- } \\
\text { rently } 0.15 \text { each on buyer and } \\
\text { seller }\end{array}$ \\
\hline Austria & $0.15 \%$ & $0.15 \%$ & - & & Present \\
\hline Belgium & $0.17 \%$ & $0.07 \%$ & $0.07 \%$ & & Present \\
\hline Brazil & $0.3 \%[0.38 \%] \quad 0$ & $0.3 \%[0.38 \%]$ & $0.3 \%[0.38 \%]$ & - & $\begin{array}{l}\text { Tax on foreign-exchange trans- } \\
\text { actions reduced from } 2 \% \text { to } 0.5 \% \\
\text { 1999. Tax on stocks increased } \\
\text { and on bonds reduced June } 1999\end{array}$ \\
\hline Chile & $\begin{array}{c}18 \% \text { VAT on } \\
\text { trade costs }\end{array}$ & $\begin{array}{c}18 \% \mathrm{VAT} \text { on } \\
\text { trade costs }\end{array}$ & - & - & Present \\
\hline China & $0.5 \%$ or $0.8 \%$ & {$[0.1 \%]$} & - & - & $\begin{array}{l}\text { Tax on bonds eliminated } 2001 \text {. } \\
\text { Higher rate on stock transac- } \\
\text { tions applies to Shanghai ex- } \\
\text { change }\end{array}$ \\
\hline Colombia & $1.50 \%$ & $1.5 \%$ & $1.50 \%$ & - & Introduced June 2000 \\
\hline Denmark & {$[0.5 \%]$} & {$[0.5 \%]$} & - & - & $\begin{array}{l}\text { Reduced in 1995, 1998. Abolished } \\
\text { effective Oct. } 1999\end{array}$ \\
\hline Ecuador & {$[0.1 \%]$} & $1.0 \%$ & - & - & $\begin{array}{l}\text { Tax on stocks introduced } 1999 \text {, } \\
\text { abolished } 2001 \text {. Tax on bonds in- } \\
\text { troduced } 1999\end{array}$ \\
\hline Finland & $1.60 \%$ & - & - & & $\begin{array}{l}\text { Introduced January } 1997 \text {; ap- } \\
\text { plies only to trades off HEX } \\
\text { (main electronic exchange) }\end{array}$ \\
\hline France & $0.15 \%$ & See note & & - & Present \\
\hline Germany & {$[0.5 \%]$} & $0.4 \%$ & $0.2 \%$ & - & Removed 1991 \\
\hline Greece & $0.60 \%$ & $0.60 \%$ & - & - & Imposed 1998; doubled in 1999 \\
\hline Guatemala & $3.00 \%$ & $3.00 \%$ & See note & - & Present \\
\hline Hong Kong & $.3 \%+\$ 5$ stamp fee & e $[0.1 \%]$ & {$[0.1 \%]$} & - & $\begin{array}{l}\text { Tax on stock transactions re- } \\
\text { duced from } 0.6 \% 1993 \text {; tax on } \\
\text { bonds eliminated Feb. } 1999\end{array}$ \\
\hline India & $0.50 \%$ & $0.5 \%$ & - & - & Present \\
\hline Indonesia & $\begin{array}{l}0.14 \%+10 \% \\
\text { VAT on } \\
\text { commissions }\end{array}$ & $0.03 \%$ & $0.03 \%$ & - & Introduced 1995 \\
\hline Ireland & $1.00 \%$ & - & - & - & Present \\
\hline Italy & [1.12\%] & - & - & - & Stamp duties eliminated 1998 \\
\hline Japan & $\begin{array}{l}{[.1 \%]} \\
{[0.3 \%}\end{array}$ & $\begin{array}{c}{[0.08 \%]} \\
[0.16 \%]]\end{array}$ & - & - & Removed April 1999 \\
\hline Malaysia & $0.50 \%$ & $0.5 \%$ & $\begin{array}{l}.015 \% \\
{[.03 \%]}\end{array}$ & $0.0005 \%$ & Present \\
\hline Morocco & $\begin{array}{l}0.14 \%+7 \% \\
\text { VAT on } \\
\text { trade costs }\end{array}$ & $\begin{array}{l}7 \% \\
\text { VAT on } \\
\text { trade costs }\end{array}$ & $\begin{array}{l}7 \% \\
\text { VAT on } \\
\text { trade costs }\end{array}$ & & Present \\
\hline Netherlands & {$[0.12 \%]$} & {$[0.12 \%]$} & - & - & $1970-1990$ \\
\hline
\end{tabular}


TABLE 1 (Cont.)

Security Transaction Taxes around the World

\begin{tabular}{|c|c|c|c|c|c|}
\hline Country & Stocks & $\begin{array}{l}\text { Corporate } \\
\text { Bonds }\end{array}$ & $\begin{array}{l}\text { Government } \\
\text { Bonds }\end{array}$ & Futures & Detail \\
\hline Pakistan & $0.15 \%$ & $0.15 \%$ & - & - & Present \\
\hline Panama & - & - & - & - & $\begin{array}{l}\text { Stamp duties eliminated Jan. } \\
2000\end{array}$ \\
\hline Peru & $\begin{array}{l}\text { 18\% VAT on } \\
\text { trade costs }\end{array}$ & $\begin{array}{l}18 \% \text { VAT on } \\
\text { trade costs }\end{array}$ & - & - & Present \\
\hline \multicolumn{6}{|c|}{ VAT on trade costs } \\
\hline Portugal & {$[0.08 \%]$} & [0.04\%] & {$[0.008 \%]$} & & Removed 1996 \\
\hline \multicolumn{6}{|c|}{$\begin{array}{c}\text { secondary offerings }+ \\
20 \% \text { VAT on trade costs }\end{array}$} \\
\hline Singapore & $\begin{array}{c}0.05 \%+3 \% \\
\text { VAT on } \\
\text { trade costs }\end{array}$ & - & - & - & $\begin{array}{l}\text { Reduced 1994, eliminated 1998; } \\
\text { VAT present }\end{array}$ \\
\hline South Korea & $\begin{array}{l}.3 \% \\
{[.45 \%]}\end{array}$ & $\begin{array}{l}.3 \% \\
{[.45 \%]}\end{array}$ & - & - & Reduced 1996 \\
\hline Sweden & {$[1 \%]$} & - & - & - & Removed 1991 \\
\hline Switzerland & $0.15 \%$ & $0.15 \%$ & $0.15 \%$ & - & $\begin{array}{l}\text { Present; } 0.3 \% \text { on foreign securi- } \\
\text { ties, } 1 \% \text { on new issues }\end{array}$ \\
\hline Taiwan & $\begin{array}{l}.3 \% \\
{[.6 \%]}\end{array}$ & $0.1 \%$ & - & $0.05 \%$ & Reduced 1993 \\
\hline UK & $0.50 \%$ & - & - & - & Present \\
\hline Venezuela & $\begin{array}{l}0.5 \% \\
{[1 \%]}\end{array}$ & - & - & - & Reduced May 2000 \\
\hline Zimbabwe & $\begin{array}{l}0.45 \% \text { VAT } \\
\text { on trade costs }\end{array}$ & - & - & - & Present \\
\hline
\end{tabular}

[...] indicates former tax rate. Sources ambiguous as to whether tax applies to bonds in France and government bonds in Guatamala. Austria, Belgium, Finland, Germany, Italy, Japan, Mexico, Portugal and Spain also impose VAT-type taxes on commodity futures trades.

Sources: The LGT Guide to World Equity Markets [London: Euromoney Publications, 1997]; 1994 Handbook of World Stock and Commodity Exchanges [London: Blackwell Finance, 1994]; Oppenheim Securities Markets Around the World [New York: John Wiley \& Sons, 1988]; OECD Financial Market Trends [Paris: OECD, 1993]; Trends [Security Industry Association, 18 August 1994]; Taxation of Stock Transfers in Various Foreign Countries [Washington: Law Library of Congress, 1989]; Tax Notes International and World Tax Daily [www.taxbase.org]; IBFD, International Bureau of Fiscal Documentation [www.ibfd.nl].The Salmon Smith Barney Guide to World Equity Markets; Dow Jones Interactive; PriceWaterhouseCoopers Guides to Doing Business.

one percent. Still, their existence is significant in demonstrating that, at least in part, the federal government already has the apparatus in place and the experience in administering such a tax.

\section{OBJECTIONS TO STETS}

In the past decade, a large literature has developed arguing against the STET. This literature is far more detailed than merely offering a general opposition derived 
from an efficient market approach. These more specifically targeted critiques fall into three broad categories ${ }^{7}$ :

1. The STET will be ineffective at reducing financial market volatility, and may even contribute to volatility, by reducing the degree of trading and liquidity in financial markets.

2. The STET will raise the cost of capital and make risk management more difficult for non-financial firms. As such it will have a negative effect on economic growth and living standards.

3. The STET will inevitably create serious distortions between the taxed and untaxed segments of the markets. As such, funds will migrate from the taxed to the untaxed markets, and market innovations will be created to circumvent the tax. The tax will both engender a layering of market distortions without even serving as an effective revenue-generator.

We will address each of these issues in turn. We will consider the first two points on investment and volatility, however, only briefly. The last issue of the distortions created by STETs brings us to the paper's main concern, which is precisely how to design the tax in such a way that minimizes its distortionary effects.

\section{Transaction Costs and Volatility in Single Markets}

The STET aims to reduce volatility by increasing the costs of short-term speculative trading. At the same time, the impact of the STET on investors holding assets over a long term will be negligible. However, some critics argue that discouraging traders from the market may actually worsen volatility by reducing the number of market participants and thereby reducing market liquidity.

Among others, Jones and Seguin [1997] conducted an empirical study with results that supported this conclusion. Jones and Seguin created an "event study" from the May 1, 1975 policy change on Wall Street, whereby fixed commissions on the New York Stock Exchange and American Stock Exchange were abandoned in favor of negotiated commissions. In practice, this policy change led to a lowering of commissions on both exchanges. At the same time, no policy change took place concerning over-the-counter transactions. Using daily data for one year before and one year after the change in commission rules, Jones and Seguin examine daily volatility in five sample portfolios sorted by size. They conclude that reduced transaction costs on the exchanges lowered volatility. They consequently suggest that a transaction tax that raises overall transaction costs will, correspondingly, increase, rather than decrease, volatility.

In an earlier study, Roll [1989] performed a more direct test of the impact of transaction taxes (as well as price limits and official margin requirements) on market volatility. He examines the financial market behavior of 23 countries at about the time of the 1987 Wall Street crash and compares the experiences of the United States and three other countries that had no transaction tax with those in 19 countries that did have some tax. Overall, Roll finds that the transaction taxes dampened volatility, though the effect was likely insignificant. 
In a third related study, Brorsen [1991] examines the impact of increasing market frictions in futures markets through raising transaction costs, as well as increasing margins, limiting arbitrage or even banning futures trading on U.S. stock markets. As with Roll, Brorsen's results tend to support the idea that raising transaction costs and creating other market frictions reduced volatility, though his evidence is mixed. Specifically, he finds that measures to create a less liquid futures market reduce stock market volatility in the short run, but has no sustained effect over the long run.

Hau and Chevallier [2000] consider these issues for the French stock market, while $\mathrm{Hu}$ [1998] examines evidence for Hong Kong, Japan, Korea and Taiwan. These authors test the relationship between transaction costs and market volatility through a range of empirical strategies and also reach ambiguous conclusions. For the Asian markets, $\mathrm{Hu}$ finds that, with a small firm portfolio, a higher transaction tax reduces volatility from noise traders. But this result is not robust across all tests. With the French market, Hau and Chevallier test whether an increase in the tick-size regime, which affects overall transaction costs in a manner similar to a STET, reduces volatility. They find that trading with wider tick-size bands reduces volatility in the French market. However, they conclude that although the decline in volatility is statistically significant, it is small in magnitude.

Overall, the various empirical studies provide no clear conclusions regarding the relationship between transaction costs and volatility. ${ }^{8}$ Such ambiguity is consistent with the analytic point made above that three separate factors influence volatilitythe underlying performance of the nonfinancial economy, the possibilities for herd behavior to become dominant on financial markets, and the prospects for quelling a herd that has already begun. A STET, or more generally, any change in transaction costs, will have the most influence on the second factor, and, taken by itself, may have little influence on the other two. Working from such an analytic framework, it is not difficult to imagine how the results on volatility would be ambiguous.

Davidson [1998] has developed one interpretation of the Jones/Seguin clearcut result that changes in transaction taxes will do nothing to inhibit volatility, though Davidson does not consider the more ambiguous findings of the other researchers at all. Nevertheless, Davidson's discussion is especially interesting in that, unlike most other STET critics, he presents his case from an explicitly Keynesian framework. Davidson believes that STET proponents conflate a decline in volume with a decline in volatility. A STET will no doubt reduce trading volume. But such a volume decline, in Davidson's view, may well increase volatility. This is because, if we recognize, along with Keynes, that financial markets are fundamentally uncertain, then thicker markets will be more stable, provided that market participants hold a diversity of views on market conditions. When traders hold a diversity of views in thick markets, pessimists and optimists will counterbalance each other. In reducing the size of such a market, the likelihood increases that pessimists and optimists will not balance out. This, in turn, will increase volatility.

But Davidson's discussion makes clear that a diversity of views is a necessary condition for increasing market size to reduce volatility. The basic idea in both Keynes and Minsky about the nature of unstable financial markets, however, is that, far 
from encouraging a diversity of views, they encourage herd behavior, what Davidson terms a "bandwagon consensus." When markets are afflicted with a bandwagon consensus, Davidson says the appropriate policy intervention is to have a "market maker with sufficient financial resources to assure market price stability," [1998, 11].

Davidson never explains why we should assume market participants are likely to hold a diversity of views rather than, as Keynes and Minsky would have it, a broad uniformity of perspective which at times will engender herd behavior. If our concern is with inhibiting the harmful effects of herd behavior and speculative excess, it follows from Davidson's own statement that the needed policy instrument is a market-maker, such as a central bank. But how does one know when the marketmaker has sufficient resources? Clearly, we can measure the sufficiency of resources only relative to the size of the market they are seeking to influence. An effective STET is a crucial policy instrument in such a situation. First, it increases the costs of engaging in speculative behavior. But in doing so, it also reduces the size of the herd-thereby increasing the possibilities for effective market-maker counter-measures. ${ }^{9}$

\section{The Impact on Nonfinancial Investment}

The only impact of a STET about which we can be certain is that, other things equal, it will raise the transaction costs of financial market trading. Some critics of the STET draw two related conclusions from this: the STET will increase the cost of capital enough to reduce real investment; and the STET will increase the costs of risk management for nonfinancial firms enough to force firms into assuming more risk averse real investment strategies.

The literature on the determinants of real investment is, of course, voluminous. While considerable controversy still remains within the literature, a few basic results have become increasingly well-founded. For most firms, accelerator effects and cash flow effects exert predominant influence over investment. Cost-of-capital effects are often statistically significant in recent models of investment, but their relative influence is substantially weaker than accelerator and cash flow influences. ${ }^{10}$

To the extent this recent literature is sound, it suggests that, at most, a STET would have a negligible influence on investment. This is both because a low tax would have a small influence on the cost of capital, and second, because cost of capital influences, themselves, are not decisive in determining the level of investment.

But in addition, insofar as a STET is intended to provide a more stable financial environment, this will have counter-effects on both the cost of capital and, more fundamentally, investment. The cost of capital should fall if the STET succeeds in creating a less risky financial environment, therefore lowering the risk/return tradeoffs for investors. Moreover, if the STET succeeds in creating a more stable financial environment, this will enhance the opportunities for firm managers to lengthen their time horizons. As noted above, it will also strengthen the capacity of government policy to stabilize financial markets and support the growth of effective demand.

It is true, of course, that the STET will increase the costs of nonfinancial firms constructing complex risk-management portfolios (that is, themselves engaging in 


\section{TABLE 2 \\ Patterns Of Real Fixed Investment and \\ Financial Asset Acquisition For U.S. Non-Financial Corporations (Percentages)}

\begin{tabular}{lcccc}
\hline & $\mathbf{1 9 6 0 - 6 9}$ & $\mathbf{1 9 7 0 - 7 9}$ & $\mathbf{1 9 8 0 - 9 0}$ & $\mathbf{1 9 9 1 - 2 0 0 0}$ \\
\hline $\begin{array}{l}\text { Real growth of fixed investment } \\
\begin{array}{l}\text { Financial asset acquisition relative to } \\
\text { fixed investment }\end{array}\end{array}$ & 8.1 & 4.0 & 2.2 & 7.4 \\
\hline
\end{tabular}

Data are grouped by NBER Business Cycle Averages. NBER cycles are grouped on a peak-to-peak basis. For brevity, two sets of cycles-1970-74/1974-79 and 1980-81/1982-90-have been merged. Source: Flow of Funds Accounts of Federal Reserve System, Table F.102. Nominal fixed investment figures deflated by Producer Price Index.

short-term financial asset trading on an ongoing basis). If it is the case that firms benefit substantially from these strategies, however, a small STET should not alter the balance of firm's benefit/cost calculations that precede their decision to pursue such strategies. In addition, any relatively small increased costs will be countered by the benefits of the STET in creating a more stable financial environment, thereby reducing the need for such strategies.

Finally, in considering non-financial firms' performance over time, according to basic measures such as investment growth, it is not clear that active risk management strategies have made a significant positive contribution to firm performance. This conclusion is certainly suggested by the figures in Table 2, which, on an annualized cycle-to-cycle basis, shows the patterns of real fixed investment growth for nonfinancial corporations and the ratio of financial asset acquisition to fixed investment since 1960. The financial asset acquisition/fixed investment ratio is a good indicator of the extent to which nonfinancial corporations have engaged in complex risk management strategies relative creating new assets through investment.

As the table shows, the full business cycle in which fixed investment grew fastest over the period covered was 1960-69, at an average annual rate of 8.1 percent, when financial asset acquisition was at its lowest relative fixed investment expenditures, at 36.6 percent. The financial asset acquisition/fixed investment ratio then rises dramatically to 55.2 percent over the two cycles in the 1970 s, during which fixed investment growth fell to an average annual rate of 4 percent. The financial asset acquisition/fixed investment ratio fell, but only slightly, over the 1980s and 1990s cycles, without any apparent gains in terms of fixed investment growth (that is, investment fell further in the 1980s then picked up in the 1990s). Of course, one would need to study this relationship far more carefully before reaching any definitive conclusion. But, at the least it is not obvious that more risk management activities by nonfinancial firms contributed to a higher rate of real investment growth. ${ }^{11}$ 


\section{Distortionary Effects of STET}

Probably the most common critique of a STET is that it creates distortions between market segments, inviting migration and other tax-avoidance strategies. One widely-cited example of such effects was the STET imposed in Sweden in 1984, which was subsequently lifted in 1990. As Campbell and Froot [1994] discuss, this Swedish tax was narrowly targeted, applying only to trades executed through Swedish brokerage firms and did not apply to foreign trades of domestic taxpayers, even if they were of Swedish financial instruments. It also did not apply to domestic trades conducted through foreign brokerage firms. It was initially limited to equity and equityderivative trades, and only later extended to bond markets and bond derivatives. Given the narrowness of this STET, not surprisingly it created strong incentives for market participants to migrate to untaxed market segments, both within Sweden and elsewhere.

At the same time, Campbell and Froot also describe the UK "stamp tax", which, as its name suggests, is a tax on the registration of ownership of a financial asset. As such, the UK tax does not discriminate among market-makers. But the UK tax was not uniform across all financial markets. It did not apply to futures markets, and applied to options only when those options were exercised. This created incentives for investors to migrate from the spot to the derivative markets.

But even if the tax were applied across markets, another consideration is establishing an appropriate tax rate. Hubbard [1993; 1997], for example, argues that if a uniform rate, such as 0.5 percent, were applied across markets, it will have widely varying impacts, given differences in existing transaction costs in different markets. In particular, Hubbard says that a tax at this level would be devastating for derivative markets, in which existing transaction taxes are far below those for equity markets. Avoiding distortionary impacts of the tax therefore entails consideration of existing differences in transaction costs across markets.

Campbell and Froot suggest, as a first principle on which to rationalize taxes across securities, that transactions that give rise to the same pattern of payoffs should pay the same tax. They themselves, however, conclude that this approach is unworkable. Among other factors, just among equity instruments, payoff patterns can differ widely at the discretion of the firms' managers. We therefore propose a variation on this principle. Rather than comparing transactions according to the payoff patterns of the assets being traded, we suggest, to the extent possible, that securities be taxed at equal rates relative to the value of the asset being traded. Within this basic framework, we then also incorporate Campbell and Froot's second strategy for designing a consistent tax across markets, which is that the tax be assessed equivalently relative to total existing transaction costs. While this is a valuable principle, it is also problematic. As we show below, transaction costs vary widely not only across markets, but also between segments of a given market.

These are the considerations that we need to keep in mind as we turn to designing a STET that minimizes distortions to the extent possible-which is to say, is consistent, as much as possible, in its impact across markets. 


\section{Minimizing Market Distortions in Design of STET}

We propose that the U.S. STET be applied following the British model, as a "stamp duty" (that is, as a tax on the transfer of a financial instrument from one owner to another). Asset transfers would not be legally effective until they had been officially stamped. Assuming market participants place a high value on establishing legal status for their asset acquisitions and sales, the stamp requirement creates a strong disincentive against efforts to circumvent the STET.

The tax should apply to all trades and transfers. This would include trades by specialty brokers and market makers. This eliminates the ambiguity involved in determining who exactly is a market-maker in an over-the-counter market and in distinguishing between trades that are carried through to take a position as opposed to trades for the purpose of maintaining liquidity in the market.

In considering the UK experience with a stamp duty STET, Campbell and Froot [1994] discuss various ways through which efforts were still made to avoid the tax. The first is for investors to use "nominees" to hold assets in their names. The effectiveness of such an avoidance strategy can be minimized, however, as Campbell and Froot describe, as long as someone in the trading chain (either the nominee or the final asset owners themselves) at some point must pay the STET for the trade to attain legal standing. In the British case, the STET applied at penalty rates three times the ordinary rate on trades initially acquired by trading nominees.

Campbell and Froot discuss only two other ways that British market participants avoided the stamp tax STET. One is simply to trade less, which, along with raising revenue, is the aim of imposing the tax in the first place. The other strategy is to move trading into untaxed market segments, which in the British case includes the derivative markets. But this approach would not apply to the tax we propose, which would cover derivative markets as well as swaps, bonds and equities.

To maintain the principle of broadest possible applicability, we propose that the U.S. STET apply to all traders in U.S. financial markets of both domestic and foreign residents. This would also be another difference from the British tax, which did not apply to foreigners trading in the UK market. Further, the tax would apply equally to foreign transactions of U.S. nationals and corporations, as was the case with Denmark's STET [Shin 1989]. Finally, the U.S. STET would apply to trades of U.S. securities by foreigners in non U.S. markets. Even though such trades take place outside U.S. jurisdiction, holding a legal claim on the asset and income stream generated by the trade would still require legal endorsement within the U.S. Thus again, the stamp tax approach would create strong disincentives against noncompliance even for trades in foreign markets.

Tax Rates. We begin with a benchmark that the two-sided tax rate on trading equities will be 0.5 percent, so that each party to the trade pays 0.25 percent. This is the amount proposed by former House Speaker Jim Wright in his 1987 proposal. This was also the level proposed by Summers and Summers [1989] and Stiglitz [1989], and has been the benchmark figure for other studies as well [Hakkio, 1994]. It is also in line with rates on equities that have been applied elsewhere in the world. 
The 0.5 percent rate on equities then becomes our benchmark for establishing rates in other markets in a way that minimizes distortions. Our proposal is to scale the two-sided tax rate on other financial instruments as follows:
Bonds
0.01 percent per each year until bond's maturity
Futures
0.02 percent of the notional value of underlying asset
Options
0.5 percent of the premium paid for the option
Interest Rate Swaps 0.02 percent per each year until maturity of swap agree- ment.

We will explain in what follows how we derived these rates, based on the principle of equivalence with the 0.5 percent rate on equities. As we will show, establishing the impact of the STET at these proposed levels depends substantially on the existing, market-determined levels of transaction costs. In reviewing the literature on transaction costs, two basic conclusions stand out: (1) Transaction costs vary widely, both across markets and within markets, according to the size and other specific characteristics of orders; and (2) as expected, transaction costs and trading volume are inversely related. But we cannot be confident about the size of the inverse elasticity. The uncertainty about the elasticity, of course, is due in part to the fact that transaction costs, themselves, vary widely by instrument and market. In addition, evidence suggests that transaction costs have fallen sharply over the past 20 years. But even here, because of the wide range of estimates, we cannot establish this conclusion on a definitive basis. Part of the problem is that research on transaction costs and elasticities remains uneven. In any case, given these uncertainties in the data, our benchmark values are certainly not meant to be a definitive, but rather a provisional set of proposals. ${ }^{12}$

Equity Markets. Table 3 presents evidence on transaction costs in equity markets. The first set of estimates is from Stoll [1993], who estimates what he terms "trading costs in the large." These are derived from aggregate revenues of securities firms. By contrast, with what Stoll terms "trading costs in the small", one tries to examine the impact of individual trades from the perspective of either the investor or the short-run behavior of individual security prices. Stoll's estimates find that average one-sided trading costs have varied quite substantially both over time and by market. As we see in the top panel of Table 3, average costs were substantially lower for exchange-traded equities relative to over-the-counter (OTC) trades, and that for both exchange-traded and OTC trades, transaction costs fell significantly between 1980-1990. As we see, exchange-traded transaction costs fell from 0.689 to 0.285 between these years, while OTC equity transaction costs fell from 1.528 to 0.761 percent of the value of trades. Based on Stoll's 1990 figures, a 0.5 percent, twosided STET on equity trades (meaning a 0.25 percent one-sided cost) raises transaction costs on exchange-based trades to an average of .535 percent, which is still more than 30 percent below the average figure for 1980. With OTC trades, transaction costs in 1990 are still 34 percent below the 1980 figure, even after imposing the 0.5 


\section{TABLE 3}

\section{Representative Estimates of Equity Market Transaction Costs}

A. Average One-Sided Costs in US Markets
(Stoll 1993; percentage of trade value)
\begin{tabular}{cccc} 
Exchanges & \multicolumn{1}{|c}{ OTC } \\
$\underline{\mathbf{1 9 8 0}}$ & $\underline{\mathbf{1 9 9 0}}$ & $\underline{\mathbf{1 9 8 0}}$ & $\underline{\mathbf{1 9 9 0}}$ \\
0.689 & 0.285 & 1.528 & 0.761
\end{tabular}

B. One-Sided Costs on Buyer-Initiated Institutional Trades in U.S. Markets

(Keim and Madhavan 1998; percentage of trade value)

$\begin{array}{lcc} & \text { Exchanges } & \text { Nasdaq } \\ \begin{array}{l}\text { Range from smallest } \\ \text { to largest market caps }\end{array} & 1.78-0.31 & 2.85-0.24 \\ & & \\ \begin{array}{l}\text { Range from smallest } \\ \text { to largest trade size }\end{array} & 0.31-0.90 & 0.76-1.80 \\ \begin{array}{l}\text { C. Median One-Sided “Adjusted Apparent Spread” in UK SEAQ Market } \\ \text { (Reiss and Werner 1996; percentage of trade value) }\end{array}\end{array}$

$\begin{array}{ccc}\text { FTSE-100 Size Class } & \frac{\text { Medium-Size Class }}{0.71} & \frac{\text { Smaller-Size Class }}{1.31}\end{array}$

percent two-sided STET. And as we consider further below, overall transaction costs have fallen still further since 1990.

Keim and Madhavan [1998] develop one version of a "trading costs in the small" transaction cost estimate, for both the exchanges and Nasdaq. These estimates are based on estimating, on a per trade basis, both "implicit" and "explicit" trade costs for institutional equity trades. The main explicit trade cost is the commission paid to the broker for execution. The more difficult to measure implicit trading costs include three components: (1) bid-ask spreads, (2) the price impacts of large trades on markets, and (3) the opportunity costs associated with missed trading opportunities

From this approach, Keim and Madhavan find that, in the institutional market, trading costs vary substantially according to the size of trade, size of firm being traded and market. We report some of these figures in Table 3. For one thing, they find that buyer-initiated, one-sided exchange trading costs range between 0.31 for large firms and 1.78 for the smallest firms. Measured according to size and therefore difficulty of trades, one-sided buyer initiated transaction costs range between .31 and .90 percent for exchange-based trades, and between .76 and 1.80 percent for Nasdaq trades.

From these figures, we get a sense of the widely divergent impact the STET will have on transaction costs, by size of firms and by size of trades. When small firms are involved and when trades are relatively large, a two-sided, 0.5 percent STET will not add significantly to trading costs. For example, the two-sided costs of making a large trade of a small firm on Nasdaq will average 4.65 percent; a STET will add only 10.8 
percent to total transaction costs. The STET's impact will clearly be much larger when the firm being traded is larger and when the amount of the trade is smaller. Considering a second extreme case, an exchange-based trade of the largest market cap firm for the smallest trade amount will entail, on average, a .62 percent transaction cost. The 0.5 percent STET will add 81 percent to transaction costs. But even here, the STET is not out of the range of existing transaction costs. We can also be confident, though we are not providing additional direct data here, that, even with the STET, these transaction costs are still well below either the existing costs on individual trades or historical costs on institutional trades.

Finally, we report a summary of Reiss and Werner's [1996] findings, which utilizes another methodology and studies another market, the London open electronic quotation system, SEAQ, the UK equivalent to Nasdaq. They develop a new measure of transaction costs, the "adjusted apparent spread" which enables them to track discounting patterns on larger trades relative to the touch spread on smaller trades. As we see in the bottom panel of Table 3, the adjusted apparent spread on SEAQ ranges between 0.71 of trading value with large firms to 2.28 of value with the smallersized firms.

Though Reiss and Werner are studying a different market and employing a different methodology than either Stoll or Keim and Madhavan, we nevertheless see again that the orders of magnitude on estimated transaction costs are similar across samples and methodologies. Taking these all into account, one can conclude that the 0.5 percent, two-sided tax is not outside the range of what the equity markets can absorb, after of course recognizing that the STET is in fact intended to reduce speculative short-term trading to some significant degree.

Bonds. We have proposed a two-sided tax rate of 0.01 percent per each year to maturity for debt issues, to promote consistency (to minimize market distortions) in the STET's impact between stock and bond markets. In assigning this rate on bonds, we are assuming that the maturity feature of a 50-year bond is roughly equivalent to owning a share of corporate equity. With a 50-year bond, therefore, if one holds the bond to maturity, one would pay the STET for this bond purchase only once in 50 years. This is roughly equivalent to being obligated to paying the STET one time only if one purchases a share of equity then holds that share indefinitely.

The logic behind reducing the tax rate on bonds then follows this same principle. If one purchases a 25-year bond, the maximum amount of time one could own the bond after having paid the STET would be 25 years. The tax rate for a 25 -year bond, therefore, should be half that for a 50-year bond. In paying the STET on the purchase of a three-month Treasury bill, one purchases only a three-month ownership claim. The STET should therefore be 1/200 the amount for the STET on both the 50 -year bond and an equity share.

Our proposed STET would tax all government debt-federal, state, municipal and other-at a rate identical to that of private debt. This is a departure from the practice in many countries, which have explicitly exempted the transfer of government debt from taxation. It would also be a departure from the current preferential tax treatment for municipal bonds and the debt of various other state and local public agencies in the United States. However, independent of the merits in general of 
providing tax-exempt government bonds, it does not follow that these benefits should necessarily be compounded through additional preferential treatment in the secondhand trading of these assets. At the same time, the argument for extending the tax to the government bond market at all its levels is straightforward. It would be needed to maintain consistency of the tax across the government and private bond markets.

Far less research has been conducted to estimate transaction costs for bond markets relative to those for equity markets. But a sufficient body of work does now exist to enable us to broadly evaluate the size of our proposed tax relative to existing transaction costs.

Hong and Warga [1998] estimate transaction costs on bonds traded both at the NYSE Automated Bond System and the over-the-counter dealer market between March 1995 and February 1997. Their data sample includes government securities as well as corporate bonds that span the range of quality grades (from Aaa to Caa). Though their research examines these alternative market settings and bond instruments in considerable detail, their conclusion is robust across these variables. They summarize their findings as follows:

We find that estimates of the effective bid/ask spread in the dealer and exchange-markets are quite similar. Per 100 dollar par value, investment grade bonds have average spreads of about 13 cents in the dealer market and 20 cents in the ABS. High yield bonds (below Baa) have spreads of about 19 cents (per 100 dollar par value) in both the dealer and ABS markets. We also find that transaction-based prices from $\mathrm{ABS}$ and the dealer market are broadly in agreement with each other and bid quotations from dealers at Lehman Brothers. [1998, 19]

Restating their results in percentage terms, Hong and Warga find that transaction costs average between 0.13 and 0.2 percent of par values. Based on these results, the sliding-scale tax that we propose of 0.01 percent for each year to maturity would mean that a one-year bond would face a tax obligation that would be between 5 and 8 percent of total transaction costs. ${ }^{13}$ If we assume that transaction costs were invariant relative to a bond's time-to-maturity, that would also suggest that the tax obligation would be equal to total transaction costs for 13- to 20-year bonds, and that the tax would exceed total transaction costs for bonds with time-to-maturity greater than 20 years.

However, the evidence is strong, if not conclusive, that bond transaction costs are not invariant relative to time-to-maturity but rather, as with our proposed STET, rise as time-to-maturity lengthens. Hong and Warga do not themselves present evidence on this. However, another recent paper by Driessen, Melenberg, and Nijman [1999] finds that transaction costs vary positively with time-to-maturity. Driessen, Melenberg, and Nijman present their results on total costs in terms of basis points rather than relative to par values, so we cannot directly compare their results on overall levels of transaction costs with those of Hong and Warga. But we can make use of their evidence on changes in transaction costs according to time-to-maturity. 
They present direct evidence on this for Treasury bills only, ranging between 1- and 9-month bills. For their 1987-97 data sample, they find that transaction costs increase fourfold (from an average of 0.4 to 1.6 basis points) between one- and ninemonth bills. If the pattern of transaction cost increases throughout the full span of bond maturities bears any resemblance to the increases reported by Driessen, Melenberg, and Nijman, therefore, it will surely be the case that a STET on bonds based on the sliding scale we propose will remain substantially below existing transaction costs even up to 50-year bonds.

Driessen et al. also provide evidence on changes in transaction costs over time. They have grouped their data on Treasury bills into two time periods, 1972-97 and 1987-97. By removing 1972-86 from the data sample, they find that transaction costs fell by between 70 and 76 percent, varing by the maturity of the instrument in their sample. Assuming this finding is broadly consistent with other bond instruments, it suggests that considerable range exists to implement a STET without creating a level of overall transaction costs that is even close to that which prevailed as recently as the 1970 s to mid 1980 s.

Options. Through the options market, investors can create synthetic positions for themselves through which, if the market were not taxed, they could still speculate on underlying equities and bonds without paying a STET for such activities. The principle of avoiding market distortions through taxing consistently across markets, therefore, applies with additional force in the case of options.

How should the options market be taxed in order to avoid distortions? Stiglitz [1989] has argued for taxing the strike price of the option, that is, the price at which the option is exercised. Basing the tax on the strike price, however, would be inconsistent with the incentive and pricing structure of the market. Options with strike prices that are significantly higher than the current spot price ("deep-out-of-themoney" options) do not involve a larger transfer of value, since the likelihood is lower that such options will get exercised.

To avoid distortions in taxing options, we propose instead that the options market STET be based on the premium paid for the option (that is, the price paid for acquiring the option). By taxing the premium, we are targeting the tax on the asset actually being traded with an options contract, which is the right to acquire another asset. Moreover, unlike the strike price, the premium incorporates the market's evaluation of the option itself, including the time limits for exercising the option and the difference between the strike price, the market price of the underlying asset at the time of purchase, and the price history of the underlying asset. In short, taxing the strike price of an option is exactly equivalent to taxing the purchase price of a stock or bond. In all three of these cases, and as distinct from taxing the strike price of an option, the price on which the tax would be scaled would fully reflect the market's valuation of all the attributes of the asset being traded..$^{14}$

As an initial working figure, we propose that options be taxed at 0.5 percent of their premium. Setting the tax at this rate follows from the assumption that the premium price of an option reflects this asset's market value in the same way that a share price, which we would also tax at 0.5 percent, reflects the market valuation of equity. If anything, based on the careful research of Diltz and Swidler [1993], this 
TABLE 4

Option Market Transaction Costs for 10 Actively Traded Firms Transaction Costs as pet. of Call Option Premium

\begin{tabular}{lcc}
\hline & $\begin{array}{c}\text { Shorter-Term (“Nearby") } \\
\text { Options }\end{array}$ & $\begin{array}{c}\text { Longer-Term(“Distant”) } \\
\text { Options }\end{array}$ \\
\hline Mean Value & $14.6 \%$ & $8.2 \%$ \\
Range for 10 firms & $4.9-21.3 \%$ & $3.1-12.7 \%$ \\
\hline
\end{tabular}

Firms included are Bristol Myers, Dow Chemical, Eastman Kodak, Ford Motor, General Electric, General Motors, Hewlett Packard, IBM, Merck, and Exxon. Figures are for 1988. Source: Diltz and Swidler 1993

figure may perhaps be too low for maintaining consistency across markets. Diltz and Swindler estimated observed transaction costs for 10 actively traded Chicago Board Options Exchange (CBOE) call options for the calendar year 1988. The analysis was restricted to the nearest-to-the-money calls, to mitigate potential biases resulting from combining the near-to-the-money options with the distinct in- and out-of-themoney markets.

The results of their study are summarized in Table 4. As the table shows, their results are grouped according to whether the options are shorter-term ("nearby") or longer-term (distant). The shorter-term options have consistently higher transaction costs as a proportion of the option premium. For shorter-term options, transaction costs for the ten firms range between 4.9 and 21.2 percent of the option premium, with an average 14.6 percent. With the longer-term options, transaction costs range between 3.1 and 12.8 percent of the premium call price, with an average 8.2 percent.

Given this range for transaction costs, the imposition of a 0.5 percent tax would have a substantially smaller impact, on average, than would be true for equity markets. With the shorter-term options, the 0.5 percent tax would amount to about three percent of average transaction costs as measured by Diltz and Swidler, and would amount to about six percent of transaction costs for longer-term options. By contrast, we saw with equities that the range of transaction costs was large, but the tax would add somewhere between 10 and 81 percent to transaction costs, as derived from Kein and Madhavan's figures.

Of course, transaction costs on options markets are likely to have fallen significantly due to market innovations since the 1988 figures reported by Diltz and Swindler. But this doesn't necessarily imply that the transaction cost differential between the options market and other markets has changed, because costs have fallen in these other markets as well. For now, we can conclude that taxing options transactions at 0.5 percent of the option premium is within the range of a workable figure, and is, if anything, on the low side of what would be needed to maintain consistency across markets.

Futures Contracts. The taxing of futures contracts poses difficulties. There is no price of a futures contract comparable to the premium on an options contract. 
Both the initial and subsequent margin deposits that traders make with brokers are the only exchanges that take place at the initial closing of a contract and until the underlying asset is transferred. Margin deposits themselves represent only a partial source of protection to brokers against default risk by traders, the other form of protection being the practice of marking to market each trader's account. Nevertheless, as long as margins are adjusted through the daily marking to market, they most accurately represent the market's valuation of the right to own a futures contract. One might therefore argue that taxing the margin deposits on futures contracts is the most appropriate approach to a STET on futures contracts. However, this logic has a significant problem: in taxing margins, we would be creating an incentive to minimize margins, which itself could contribute to market instability.

Other countries that have imposed STETs on futures markets have adopted three alternative strategies. France and Hong Kong imposed a flat fee on a per contract basis. Japan taxed the notional value of the underlying asset (that is, if one has bought a futures contract providing the right to purchase a $\$ 100$ bond at some point in the future, the STET in this Japanese system would be established as some fraction of the $\$ 100$ bond). Finland, the third case, taxed the gains or losses in trading value on the contract sold or bought. In other words, if one had purchased the right to buy a given bond on a specific date at the fixed price of $\$ 100$, and the market value of that bond was selling at $\$ 110$ on the date of purchase, the tax would be a percentage of the $\$ 10$ profit accruing to the holder of the futures contract.

In terms of setting the tax in a way that is consistent with other markets, the French/Hong Kong flat fee approach falls short, because it would obviously entail a heavier proportional burden for smaller-sized contracts, thereby encouraging larger contracts. The Finnish approach of taxing trading gains or losses would be an ex post tax, and would not be taxing the transaction itself but rather only the profit derived from the transaction.

The Japanese approach is most consistent with our aim of minimizing distortions, because the tax is levied on all transactions and the tax rate is being set in proportion to the value of the asset being traded. Relative to the tax on the margin deposit, however, it is less clear what the appropriate tax rate would be on the notional value of futures assets, while maintaining consistency across markets. Before being lifted in April 1999, the tax in Japan had ranged between 0.002 and 0.005 percent of notional value. This level of taxation on futures was applied along with a range of between 0.3 and 1.0 percent on equities and 0.08 and 0.16 percent on corporate bonds. Working from this Japanese model, we propose to operate from an initial rate of 0.002 percent of notional value. To determine the appropriateness of this rate, we can then invoke our second standard of tax consistency, (that is, establishing tax rates relative to existing transaction costs). Fortunately, we have adequate data on futures markets transaction costs to undertake this exercise.

Futures Market Transaction Costs. Although the literature in this area is far less developed than that for equity markets, the recent work of Locke and Venkatesh [1997] and Wang, Yau and Baptiste [1997] does provide a substantial basis for formulating generalizations. 
TABLE 5

Futures Market Transaction Cost Estimates

\begin{tabular}{|c|c|c|c|c|c|c|}
\hline & \multicolumn{3}{|c|}{ Commodity } & \multicolumn{3}{|c|}{ Range of Estimates } \\
\hline & \multicolumn{3}{|c|}{ Live Hogs } & \multicolumn{3}{|c|}{$0.0337-0.0618$} \\
\hline & \multicolumn{3}{|c|}{ Pork Bellies } & \multicolumn{3}{|c|}{$0.0488-0.0958$} \\
\hline & \multicolumn{3}{|c|}{ Live Cattle } & \multicolumn{3}{|c|}{$0.0077-0.0397$} \\
\hline & \multicolumn{3}{|c|}{ Lumber } & \multicolumn{3}{|c|}{$0.0609-0.1480$} \\
\hline & \multicolumn{3}{|c|}{ Feeder Cattle } & \multicolumn{3}{|c|}{$0.0211-0.0519$} \\
\hline & \multicolumn{3}{|c|}{ Canadian Dollar } & \multicolumn{3}{|c|}{$0.0093-0.0187$} \\
\hline & \multicolumn{3}{|c|}{ Swiss Franc } & \multicolumn{3}{|c|}{$0.0038-0.0239$} \\
\hline & \multicolumn{3}{|c|}{ Deutsche Mark } & \multicolumn{3}{|c|}{$0.0058-0.0204$} \\
\hline & \multicolumn{3}{|c|}{ Pound Sterling } & \multicolumn{3}{|c|}{$0.0025-0.0173$} \\
\hline & \multicolumn{3}{|c|}{ Japanese Yen } & \multicolumn{3}{|c|}{$0.0053-0.162$} \\
\hline & \multicolumn{3}{|c|}{ S\&P 500 Index } & \multicolumn{3}{|c|}{$0.0030-0.0089$} \\
\hline \multicolumn{7}{|c|}{ Summary Statistics } \\
\hline Low Estimates: & Mean & 0.0184 & Median & 0.0077 & S.D. & 0.0021 \\
\hline High Estimates: & Mean & 0.0589 & Median & 0.0397 & S.D. & 0.0538 \\
\hline
\end{tabular}

Transaction costs as a percentage of notional value of contracts derived from Locke and Venkatesh 1997.

Table 5, derived from Locke and Venkatesh, shows a range of estimates of transaction costs in eleven different futures markets. Locke and Venkatesh themselves generated one set of estimates, based on measuring direct transfers of funds from customers to market-makers. They also report results derived from two separate techniques based on considering market-wide bid-ask spreads.

Without considering the relative merits of the alternative estimating techniques, ${ }^{15}$ we see substantial variation in estimates according to the technique being used. Just considering mean values, the mean low figure, a one-way cost of 0.0184 of notional value, is more than three times smaller than the mean one-way high of 0.0589 . The full range between low and high values is obviously larger still.

But for our purposes, the main finding is that our proposed two-way tax rate of 0.02 percent of notional value is well inside the existing transaction cost structure of the futures market. Our proposed tax rate would amount to roughly 5 percent of the mean one-way low estimate for these 11 markets, and 1.5 percent of the mean oneway high estimate. If anything, as with options, the tax on futures might need to be somewhat higher to retain equivalence with equity and bond markets relative to each market's private transaction costs.

Table 6 reports price elasticities of trading developed by Wang, Yau and Baptiste. To our knowledge, this is the most recent research done on trading elasticities with respect to any financial markets. The most recent work done on estimating equity market trading elasticities, again to our knowledge, was that by Epps, which was published in 1976, relying on 1968 data. Epps found a trading elasticity for equities of -0.26 . 
TABLE 6

\section{Futures Market Trading Volume Elasticities as \\ Function of Transaction Costs (elasticity percentages)}

\begin{tabular}{cl}
\hline Financial Futures & \\
Treasury Bond & -1.169 \\
S \& P 500 & -2.03 \\
Deutsch Mark & -2.72 \\
Agricultural Futures & \\
Wheat & -0.116 \\
$\quad$ Soybeans & -0.165 \\
Mineral Futures & -2.29 \\
Copper & -2.64 \\
Gold & \\
\hline
\end{tabular}

[Wang, Yau, and Baptiste, 1997]

As we see, the futures markets trading elasticities vary tremendously across markets, ranging from -2.72 for Deutsche mark futures to -0.116 for wheat futures (although the result for wheat is not statistically significant). To explain their findings Wang, Yau, and Baptiste argue that elasticities are highly sensitive to whether the markets in which these commodities are traded have close substitutes. The closest such substitute market would be overseas markets in which the same commodities trade. This is why the elasticities of the financial and metals futures are higher than those for agricultural futures.

Interest Rate Swaps. ${ }^{16}$ Swap markets are far less standardized than options or futures markets, because the value of the swap transaction itself has a clear market measure comparable to the premium on an option. Alternatively, a swap transaction is, over the period specified for the exchange, equivalent to the transfer of ownership of an asset. The primary difference is that instead of exchanging money now for the claim on the income from an asset, the counterparties exchange each other's income claims on two separate assets.

As such, the principle to follow for a STET on swaps would be the same as that for stocks and bonds. That is, the appropriate tax rate should be 0.01 percent of the value of the underlying assets per year until the asset's maturity. In this case, however, the duration of the swap agreement would be the measure of the years until maturity. If counterparties agreed on a "plain vanilla" swap over five years of a fixed and floating rate government bond, therefore, the tax would be 0.05 percent, regardless of the maturities of the two underlying bonds themselves. 


\section{REVENUE ESTIMATES FROM U.S. STET ${ }^{17}$}

Table 7 presents revenue estimates for the STET we have developed, based on levels of market activity for the full year 1997 for stock, bond and swap markets, and $3 / 99$ data for futures and options markets.

Because of the uncertainties associated with transactions costs and elasticities, it is not possible to generate a reliable point estimate of the STET's revenue potential. We have opted for a less exacting approach, which is to establish rough orders of magnitude for our revenue estimates (and no more than that) using the tax rates we have discussed throughout the text, which are listed in the second column of the table.

As Table 7 shows, we provide three rough tax revenue estimates. Our first set of figures is based on the assumption that market values of securities and trading volume remain unchanged from the 1997 levels after the imposition of the STET. Under this circumstance, the STET generates $\$ 132.1$ billion of revenue.

But of course, in addition to raising revenue, the purpose of the STET is to discourage speculative market trading, so it is unrealistic to assume that trading volume and prices will remain constant after the STET is implemented. The next column of figures assumes that trading volume falls by 25 percent after the STET is implemented. This 25 percent figure for trading volume decline seems implausibly high, given the evidence we have on the magnitude of the tax we propose relative to actual transaction costs over the recent past. ${ }^{18}$ Nevertheless, allowing for such a large decline in trading provides an informative benchmark. Based on this assumption, we see that our tax revenue estimate is still $\$ 99.2$ billion. Now mainly to provide an outside estimate, in the rightward column of Table 7 , we show revenue figures assuming trading volume falls by 50 percent after implementation of a STET. Even under this circumstance, we see that the U.S. STET generates $\$ 66.1$ billion.

Of course, these revenue estimates would have been higher during 2000, when the stock market peaked. We can obtain a sense of the revenue potential with the 2000 market through the actual revenue figures generated by the existing SEC tax of 0.0033 percent on stock transactions. This tax alone-as distinct from the 0.034 percent stock registration fee-generated $\$ 1.1$ billion in 2000 . As a hypothetical exercise, if we raise the stock transaction tax rate to 0.5 percent and assume no decline in trading volume, the 2000 revenue generated by the tax would be $\$ 184$ billion, (that is, more than three times the $\$ 54.9$ billion for revenue in equity trades we have estimated, based on 1997 stock market activity). As such, even allowing for the nearly 40 percent drop in the market in the two full years since the August 2000 peak (according to the S\&P 500 index), and assuming the revenues from the SEC STET fell by an equivalent 40 percent, that would still mean that the STET from stock trades alone would generate $\$ 110$ billion. In other words, this rough exercise suggests that our revenue estimates based on the 1997 market would offer a broadly accurate order of magnitude estimate for the revenue potential of a STET designed along the lines we propose. 
TABLE 7

Revenue Estimates for U.S. STET

(Estimates based on 1997 data except as noted)

\begin{tabular}{|c|c|c|c|c|}
\hline & $\begin{array}{r}\text { Rever } \\
\mathbf{v} \\
\text { pric } \\
\text { (b }\end{array}$ & $\begin{array}{c}\text { Revenue estimates } \\
\text { with no } \\
\text { volume or } \\
\text { price reduction } \\
\text { (billions \$) }\end{array}$ & $\begin{array}{l}25 \text { percent } \\
\text { volume } \\
\text { reduction } \\
\text { (billions \$) }\end{array}$ & $\begin{array}{l}50 \text { percent } \\
\text { volume } \\
\text { reduction } \\
\text { (billions \$) }\end{array}$ \\
\hline Equities & 0.5 percent of asset value & 54.9 & 41.2 & 27.5 \\
\hline Government Bonds & 0.01 percent of asset value & 41.6 & 31.2 & 20.8 \\
\hline Corporate Bonds & per number of years to maturity & 22.1 & 16.6 & 11.1 \\
\hline Futures & $\begin{array}{l}0.002 \text { percent of notional } \\
\text { value of underlying asset }\end{array}$ & 2.6 & 2.0 & 1.3 \\
\hline Options & 0.5 percent of option premium & 6.5 & 4.9 & 3.3 \\
\hline Swaps & $\begin{array}{l}0.02 \text { percent of asset value, } \\
\text { per number of years to maturity }\end{array}$ & 4.4 & 3.3 & 2.2 \\
\hline Totals & & 132.1 & 99.2 & 66.1 \\
\hline
\end{tabular}

Futures and Options based on data from Wall Street Journal, 3/17/99. Sources: Securities Industry Association Factbook 1998; Securities Industry Association Investor Activity Report 1993; Federal Reserve Bulletin, Table 1.42; Futures and Options Factbook 1999; International Swap Dealers Association Market Survey 1997 Market Activities Data.

\section{CONCLUSION}

The U.S. Congress has regularly considered proposals for a U.S. STET since 1987, when a bill was introduced by then House Speaker Jim Wright. Perhaps the steady stream of academic literature opposed to a STET has been a factor in preventing the measure from moving in Congress beyond the level of initial discussions. In this paper, we respond to the academic critics, and show that a STET can be designed in such a way that it is both desirable and workable in the U.S. context.

A STET is desirable along different dimensions. First, it is a measure that can contribute toward mitigating the "predominance of speculation over enterprise," as Keynes put it. Of course, critics are correct in arguing that, by itself, a STET could not prevent excessive financial trading, unless the tax is set at a level that would likely also inhibit "enterprise-driven," as well as "speculation-driven," forms of trading. But a STET can make a significant contribution toward dampening excessively speculative financial markets. It can do so first, in precisely the manner described by Tobin, by penalizing short-horizon round trips and thereby reducing the level of such short-term trading; while negligibly affecting those involved in long-term investment activity. But in addition, as speculative trading declines due to the STET, the capacity of policymakers to intervene as market makers increases, because the market they will be trying to influence will be smaller. This will also increase the 
effectiveness of monetary and fiscal policy interventions, because such interventions could be conducted with less concern about how speculative markets might respond.

As we have shown, the revenue potential of a STET is formidable. A STET in the United States that raises $\$ 100$ billion per year-which at the 2002 level of financial market trading, even after the stock market collapse, would occur at lower tax rates than those we have proposed-would be sufficient to increase, for example, all federal spending on education, training, employment and social services by 154 percent over its 2001 level. This again highlights the "win-win" feature of a STET: if it fails to dampen speculation, it will nevertheless be generating an even larger amount of revenue, taxing unproductive market trading on a highly progressive basis. As policymakers gain experience in administering the STET, they could then also adjust the tax rates periodically, depending on whether their primary aim at a given time was to discourage speculative trading or raise revenue.

Finally, we have shown that a STET can be implemented in a way that will avoid serious distortions across financial market segments, and thereby the flourishing of tax sheltering strategies, as occurred with the narrowly targeted Swedish STET. We have designed a STET that is consistent across markets by following two simple principles: first that securities be taxed at equivalent rates relative to the value of assets being traded; and second, that taxes be assessed equivalently relative to existing transaction costs in the various market segments. Incentives for tax avoidance will be weakened further through following the British Stamp Tax example (that is, granting legal status to ownership transfers only after the STET has been paid).

Given the fact that the U.S. government currently imposes a small STET to finance SEC operations, (and raises over $\$ 1$ billion each year in revenue through this tax) the overall evidence is strong that instituting a larger and broader STET would be a workable as well as desirable policy measure.

\section{NOTES}

We are extremely grateful for the research assistance and the critical readings of this work by Lawrance Evans Jr., James Heintz, and Josh Mason; and for the additional comments of Randall Dodd, Jerry Epstein, and Tom Palley and seminar participants at the Jerome Levy Institute of Bard College, the Center for Economic and Policy Analysis of the New School University, the Political Economy Research Institute at the University of Massachusetts, the January 2003 New Rules for Global Finance conference on the Tobin Tax, and the February 2003 Eastern Economic Association meetings. We also gratefully acknowledge the financial support from the Ford Foundation for the PERI project on Stable and Egalitarian Growth in the Age of Global Integration.

1. Overviews of this efficient market framework are presented in Hubbard [1996, passim], Raines and Leathers [2000, Ch. 3], Shleifer [2000, Ch. 1], and Evans [2003, Chs. 2-3].

2. This recent literature is summarized in Xiao [2003]. Xiao also focuses on the specific experience of China, demonstrating econometrically that real investment in China has become significantly influenced by the movement of stock prices, but the stock prices themselves do not correspond in any systematic way to "fundamentals."

3. Whether these valid performance standards are accounted for in an accurate or even honest fashion by corporations is separate issue.

4. Pollin [2003] provides describes the connections between the collapse of the 1990s bubble and the 2001 recession in the U.S. But even earlier, the imbalances created by this bubble were well-documented by 
Baker [2000a, 2000b], Godley [2000], Godley and Izurieta [2001], among others. Kindleberger [1978] discusses the problem of financial instability over a 250-year history of Western capitalism between 1720-1975, developing his analytic framework from Hyman Minsky's Keynesian theory of endogenous financial fragility.

5. One can readily extract these three sources of volatility over a business cycle via the Minsky analysis of systemic financial instability [see Minsky 1986, Dymski and Pollin 1994]. Madhavan, Richardson, and Roomans [1997] conduct a distinct exercise in seeking to decompose and measure the sources of equity price volatility over the course of a trading day.

6. Details on the SEC budget are available at www.sec.gov.

7. A representative sample of this research includes Gruenfest and Shoven [1991], Umlauf [1993], Hakkio [1994], Campbell and Froot [1994], Lerman [1996], Jones and Seguin [1997], Davidson [1998] and Habermeier and Kirilenko [2001]. Many of these arguments are pulled together in Hammond [1997]. This volume collects papers by Schwert and Seguin, Hubbard, Heaton and Ho, Campbell and Froot, and McConnell.

8. The IMF working paper by Habermeier and Kirilenko [2001] acknowledges the ambiguity of these empirical findings

9. In a separate paper, Davidson [1997] advances a related argument in opposing the Tobin tax version of the STET specifically-that the 0.5 percent one-way tax rate proposed by Eichengreen, Tobin and Wyplosz [1995] would be too low to discourage speculative sales of a currency in a crisis period of sharp price declines. Our discussion above agrees with the thrust of Davidson's position that a STET is not an effective policy instrument for inhibiting speculative sell-offs once a crisis has begun. The main purpose of the STET, rather, is to prevent the volume of speculative trading from becoming so large that a central bank, or other market maker, has no other effective tools for dampening the effects of speculative attacks once they have begun. There is an additional issue that Davidson's 1997 paper raises. While Davidson argues that the tax rate that Eichengreen, Tobin and Wyplosz propose is too low for discouraging speculative runs on currencies, it is clearly the case that the rates on STETS can be increased or lowered, as appropriate, depending on whether the main purpose of the tax is to discourage the build-up of speculative trading or to raise revenue.

10. Kopcke's comprehensive econometric "horse race" on U.S. investment behavior [summarized in Berndt, 1991] finds that accelerator and profit/cash flow effects are significantly more powerful than cost of capital/interest rate changes. Chirinko's similarly comprehensive survey [1993] reaches similar conclusions. This same basic result is supported by Fazzari's [1993, 1994, and 1988 with Hubbard and Peterson] innovative micro-level research on the determinants of investment, as well as Binswanger's more recent model [1999], which also explicitly tests stock market movements as a determinant of investment.

11. In addition, it is never the case that corporate risk management strategies reduce the level of social risk associated with productive activity, when the profitability of such projects is inherently uncertain. At best, then, risk management strategies distribute the burden of inherent uncertainty more broadly among the community of asset owners.

12. While our tax rate figures are provisional, they nevertheless represent what we believe are appropriate orders of magnitude for a U.S. STET. Perhaps some STET proponents, for various reasons, would favor raising rates sufficiently high as to render all financial market trading prohibitive. This is certainly not our intention, and it seems implausible that any such proposals could gain a serious hearing in the U.S.

13. That is, the tax on the one-year bond is 0.01 of par value while the transaction costs are between 0.13 -0.20 . The tax would therefore equal between $0.01 / 0.13$ and $0.01 / 0.20$, i.e. between $5-8$ percent of transaction costs.

14. Dr. Randall Dodd of the Derivatives Study Center has argued to us that a better approach to minimizing distortions across markets would be to tax the notional values of derivative assets at the same rate as the underlying assets - that is, for example, to tax a $\$ 100$ option on an equity share at the same 0.5 percent rate at which we would tax the purchase of the equity itself. Dodd holds that this approach would better reflect the fact that, in purchasing both the option or the underlying equity itself, the aim is to bet on the future price movements of the asset. Dodd's approach has merit in principle. But in our view, the most effective way to implement a workable tax across markets is with respect to the exist- 
ing level of transaction costs in the various markets. Dodd's approach would not take account of this concern.

15. Though Locke and Venkatesh themselves consider this issue at length.

16. We have not explicitly examined the issue of taxing the market for repurchase agreements. But there are large similarities between the "repo" market and that for swaps. As such, our general approach to taxing swaps would also apply with respect to the repo market.

17. Our attempt at providing a rough estimate of revenue potential follows in spirit, if not specific methodology, the work of Felix and Sau [1996]

18. At the same time, there does not exist any significant body of evidence on how security prices might react to changes in either transaction costs or trading volume. From an efficient markets perspective, a small rise in transaction costs should have no effect on security price levels, if, indeed, security prices are determined by each firm's fundamentals. From a critical Keynesian or behavioral finance perspective, there is also no reason to expect that a small change in transaction costs would affect the mean level of security prices in any significant way, even while, by discouraging speculative trading, it should have some impact on the fluctuations around the mean prices.

\section{REFERENCES}

Arestis, P., Demetriades, P. and Luintel, K. Financial Development and Economics Growth: The Role of Stock Markets. Journal of Money, Credit, and Banking, February 2001, 16-41.

Baker, D. Double Bubble: The Overvaluation of the Stock Market and the Dollar. 2000a. [On-line]. Available at http://www.cepr.net/columns/baker/double_bubble.htm

. The Costs of the Stock Market Bubble. 2000b. [On-line]. Available at http://www.cepr.net/ stock_market_bubble.htm

Berndt, E. The Practice of Econometrics: Classic and Contemporary. Reading, MA: Addison-Wesley, 1991.

Bhagwati, J. Directly Unproductive Profit-Seeking Activity. Journal of Political Economy, October 1982, 998-1002.

Binswanger, M. Stock Markets, Speculative Bubbles, and Economic Growth. Northampton, MA: Edward Elgar, 1999.

Brorsen, W. Futures Trading, Transaction Costs, and Stock Market Volatility. The Journal of Futures Markets, April/May 1991, 153-63.

Campbell, J. and Froot, K. International Experiences with Securities Transaction Taxes in The Internationalization of Equity Markets, edited by J. Frankel. Chicago: University of Chicago Press, 1994. 277-308.

Chirinko, R. Business Fixed Investment Spending: Modeling Strategies, Empirical Results, and Policy Implications. Journal of Economic Literature, December 1993, 1875-1911.

Davidson, P. Are Grains of Sand in the Wheels of International Finance Sufficient to do the Job When Boulders are Often Required? Economic Journal, May 1997, 671-86.

- Volatile Financial Markets and the Speculator. Economic Issues, September 1998. [Online]. Available at http://econ.bus.utk.edu/davidsonextra/Res8fnl.html

Diltz, J. D. and Swidler, S. A Comparison of Actual and Theoretical Transaction Cost Estimates for CBOE-Listed Options. Advances in Futures and Options Research, 1993, 355-65.

Driessen, J., Melenberg, B. and Nijman, T. Testing Affine Term Structure Models in case of Transaction Costs. Manuscript, Tilberg University, 1999. [On-line.] Available at http://center.kub.nl/phd_stud/ jdries/index.htm

Dymski, G. and Pollin, R., eds. New Perspectives in Monetary Macroeconomics: Explorations in the Tradition of Hyman P. Minsky. Ann Arbor, MI: University of Michigan Press, 1994.

Eichengreen, B., Tobin, J. and Wyplosz, C. Two Cases for Sand in the Wheels of International Finance. Economic Journal, January 1995, 162-72.

Epps, T. The Demand for Brokerage Services: The Relation between Securities Trading Volume and Transaction Costs. Bell Journal of Economics, Spring 1976, 163-96.

Evans, L., Jr. Why the Bubble Burst: Explaining the U.S. Stock Market, 1982-2000, Northampton, MA: Edward Elgar, 2003.

Fazzari, S. Monetary Policy, Financial Structure, and Investment, in Transforming the U.S. Financial System, edited by G. Epstein, G. Dymski and R. Pollin. Armonk, NY: M.E. Sharpe, 1993, 35-64.

- Why Doubt the Effectiveness of Keynesian Fiscal Policy? Journal of Post Keynesian Economics, Winter 1994-95, 231-48. 
Fazzari, S., Hubbard, G. and Peterson, B. Financing Constraints and Corporate Investment. Brookings Papers on Economic Activity, 1988, 141-206.

Felix, D. and Sau, R. On the Revenue Potential and Phasing in of the Tobin Tax, in The Tobin Tax: Coping with Financial Volatility, edited by M. Ul Haq, I. Kaul and I. Grunberg. New York: Oxford University Press, 1996, 223-54.

Godley, W. Seven Unsustainable Processes: Medium-Term Prospects and Policies for the United States and the World. 2000. [On-line.] Available at http://www.levy.org/

Godley, W. and Izurieta, A. As the Implosion Begins . . ? 2001. [On-line.] http://www.levy.org/

Gruenfest, J. and Shoven, J. Adverse Implications of a Securities Transaction Excise Tax. Journal of Accounting, Auditing, and Finance, Fall 1991, 409-42.

Habermeier, K. and Kirilenko, A. Security Transaction Taxes and Financial Markets. 2001. [On-line.] Available at http://www.imf.org/external/pubs/ft/wp/2001/wp0151.pdf

Hakkio, C. Should We Throw Sand in the Gears of Financial Markets? Economic Review, Federal Reserve Bank of Kansas City, Second Quarter 1994, 17-30.

Hammond, S. ed. Securities Transaction Taxes: False Hopes and Unintended Consequences, Chicago: Irwin Professional Publishers, 1997.

Hau, H. and Chevallier, A. Estimating the Volatility Effect of a Security Transaction Tax. 2000. [Online.] Available at http://faculty.insead.fr/hau/Research/tobin46.pdf

Hong, G. and Warga, A. An Empirical Study of Bond Market Transactions. Research Report, Bond Market Association. 1998. [On-line.] Available at http://bondmarkets.com

Hu, S. The Effects of the Stock Transaction Tax on the Stock Market_Experiences from Asian Markets. Pacific-Basin Finance Journal, August 1998, 347-64.

Hubbard, R. Securities Transaction Taxes: Tax Design, Revenue, and Policy Considerations. Tax Notes, November 22, 1993, 985-1000.

. Money, the Financial System, and the Economy, 2nd ed. Reading, MA: Addison-Wesley, 1996.

- Securities Transaction Taxes: Can They Raise Revenue? in Securities Transaction Taxes: False Hopes and Unintended Consequences, edited by S. Hammond. Chicago: Irwin Professional Publishers, 1997, 27-57.

Japanese Securities Research. Securities Markets in Japan. Tokyo: Japan Securities Research Institute, 1992.

Jones, C. and Seguin, P. Transaction Costs and Price Volatility: Evidence from Commission Deregulation. American Economic Review, September 1997, 728-37.

Keim, D. and Madhavan, A. The Cost of Institutional Equity Trades. Financial Analysts Journal, July/ August 1998, 50-69.

Keynes, J. The General Theory of Employment, Interest, and Money. New York: Harcourt Brace \& World, 1936.

Kindleberger, C. Manias, Panics, and Crashes, New York: Basic Books, 1978.

Lerman, R. Securities Turnover Excise Tax (STET): A Brief Overview of the Issues. Unpublished typescript, The Urban Institute, 1996.

Levine, R. and Zervos, S. Stock Markets, Banks, and Growth. American Economic Review, June 1998, 537-58.

Locke, P. and Venkatesh, P. Futures Market Transaction Costs. Journal of Futures Markets, April 1997, 229-45.

Madhaven, A., Richardson, M. and Roomans, M. Why Do Security Prices Change? A TransactionLevel Analysis of NYSE Stocks. Review of Financial Studies, Winter 1997, 1035-64.

Minsky, H. Stabilizing an Unstable Economy: New Haven, CT: Yale University Press, 1986.

Pollin, R. Contours of Descent: U.S. Economic Fractures and the Landscape of Global Austerity, London: Verso Press, 2003.

Poterba, J. and Summers, L. A CEO Survey of U.S. Companies' Time Horizons and Hurdle Rates. Sloan Management Review, Fall 1995, 43-53.

Raines, J. and Leathers, C. Economists and the Stock Market: Speculative Theories of Stock Market Fluctuations, Northamption, MA: Edward Elgar, 2000.

Reiss, P. and Werner, I. Transaction Costs in Dealer Markets: Evidence from the London Stock Exchange, in The Industrial Organization and Regulation of Securities Industry, edited by Andrew W. Lo. Chicago: University of Chicago Press, 1996, 125-69. 
Roll, R. Price Volatility, International Market Links, and their Implications for Regulatory Policies. Journal of Financial Services Research, December 1989, 211-46.

Shin, M. Taxation of Stock Transfers in Various Foreign Countries. Law Library of Congress Report, July 1989.

Shiller, R. Market Volatility, Cambridge, MA: MIT Press, 1989.

- Irrational Exuberance, Princeton, NJ: Princeton University Press, 2000.

Shleifer, A. Inefficient Markets: An Introduction to Behavioral Finance. New York: Oxford University Press, 2000.

Stiglitz, J. Using Tax Policy to Curb Speculative Short-Term Trading. Journal of_Financial Services Research, December 1989, 101-15.

Stoll, H. Equity Trading Costs In-The-Large. The Journal of Portfolio Management, Summer 1993, 41-50.

Subrahmanyam, A. Transaction Taxes and Financial Market Equilibrium. Journal of Business, January 1998, 81-118.

Summers, L. and Summers, V. When Financial Markets Work Too Well: A Cautious Case for a Securities Transactions Tax. Journal of Financial Services Research, December 1989, 261-86.

Tobin, J. A Proposal for International Monetary Reform. Eastern Economic_Journal, July/October 1978, 153-59.

. Prologue, in The Tobin Tax: Coping with Financial Volatility, edited by M. ul Haq, I. Kaul and I. Grunberg. New York: Oxford University Press, 1996, ix - xviii.

ul Haq, M., Kaul, I. and Grunberg, I., eds. The Tobin Tax: Coping with Financial Volatility, New York: Oxford University Press, 1996.

Umlauf, S. Transaction Taxes and the Behavior of the Swedish Stock Market. Journal of Financial Economics, April 1993, 227-40.

Wang, G., Yau, J. and Baptiste, T. Trading Volume and Transaction Costs in Futures Markets. Journal of Futures Markets, October 1997, 756-80.

Xiao, F. The Role of the Stock Market in Influencing Corporate Investment in China. Ph.D. dissertation, University of Massachusetts-Amherst, 2003.

Zhu, A., Ash, M. and Pollin, R. Stock Market Liquidity and Economic Growth: A Critical Appraisal of the Levine/Zervos Model. International Review of Applied Economics, forthcoming 2004. Also available at http://www.umass.edu/peri/pdfs/WP47.pdf 